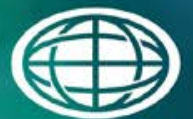

Savannah River

National Laboratory ${ }^{m}$

OPERATED BY SAVANNAH RIVER NUCLEAR SOLUTIONS

Solvent Hold Tank Sample Results for

MCU-15-815-816-817-818-819-820

November Monthly Sample

F. F. Fondeur

D. H. Jones

January 2016

SRNL-STI-2016-00016, Revision 0 


\section{DISCLAIMER}

This work was prepared under an agreement with and funded by the U.S. Government. Neither the U.S. Government or its employees, nor any of its contractors, subcontractors or their employees, makes any express or implied:

1. warranty or assumes any legal liability for the accuracy, completeness, or for the use or results of such use of any information, product, or process disclosed; or

2. representation that such use or results of such use would not infringe privately owned rights; or

3. endorsement or recommendation of any specifically identified commercial product, process, or service.

Any views and opinions of authors expressed in this work do not necessarily state or reflect those of the United States Government, or its contractors, or subcontractors.

\section{Printed in the United States of America \\ Prepared for U.S. Department of Energy}




\title{
Solvent Hold Tank Sample Results for MCU-15-815- 816-817-818-819-820: November Monthly Sample
}

\author{
F. F. Fondeur \\ D. H. Jones
}

January 2016

Prepared for the U.S. Department of Energy under contract number DE-AC09-08SR22470.

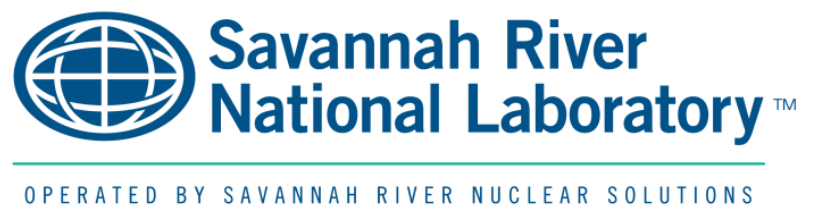




\section{REVIEWS AND APPROVALS}

\section{AUTHORS:}

F. F. Fondeur, Advanced Characterization and Processing Date

D. H. Jones, Research Support

Date

TECHNICAL REVIEW:

T. B. Peters, Advanced Characterization and Processing

Date

Reviewed per Manual E7 Procedure 2.60

APPROVAL:

A. L. Washington, Manager

Date

Advanced Characterization and Processing

D. E. Dooley, Director

Date

Environmental Stewardship

E. A. Brass, Manager

Date

MCU \& Salt/Sludge Processing 


\section{EXECUTIVE SUMMARY}

Savannah River National Laboratory (SRNL) received one set of Solvent Hold Tank (SHT) samples (MCU-15-815-816-817-818-819-820), pulled on 11/29/2015 for analysis. The samples were inspected, combined, and analyzed for composition. Chemical analysis of the composite sample MCU-15-815-816817-818-819-820 indicated the TiDG, Isopar ${ }^{\mathrm{TM}} \mathrm{L}$, and MaxCalix are at nominal levels. The modifier concentration is $3 \%$ below its nominal concentration. This analysis confirms the addition of TiDG, MaxCalix, and modifier to the solvent on November 28, 2015. Based on the current monthly sample, the levels of TiDG, IsoparTM ${ }^{\mathrm{TM}}$, MaxCalix, and modifier are sufficient for continuing operation but are expected to decrease with time. Periodic characterization and trimming additions to the solvent are recommended.

No impurities above the $1000 \mathrm{ppm}$ level were found in this solvent by the Semi-Volatile Organic Analysis (SVOA). No impurities were observed in the Hydrogen Nuclear Magnetic Resonance (HNMR). However, up to $12.5 \pm 3$ micrograms of mercury per gram of solvent (or $10.4 \mu \mathrm{g} / \mathrm{mL}$ ) was detected in this sample. The solids residues found at the bottom of the p-nut vial from sample MCU-15-815 were determined to be left-over pipe residues that were flushed into the sample and they were found to have no impact on the solvent purity or on the chemical and physical properties of the solvent.

The laboratory will continue to monitor the quality of the solvent in particular for any new impurities or degradation of the solvent components. 


\section{TABLE OF CONTENTS}

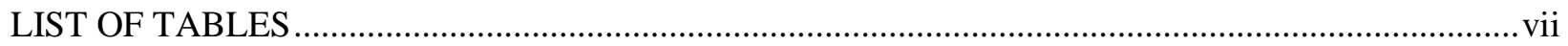

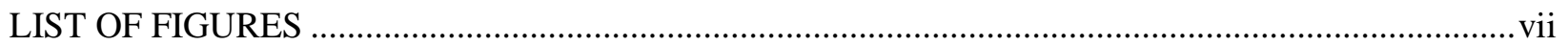

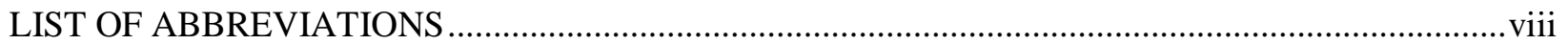

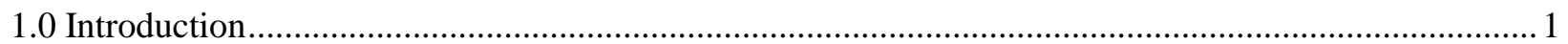

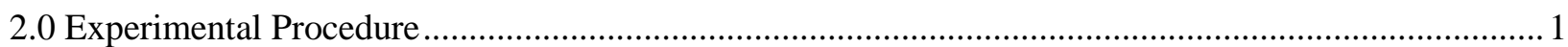

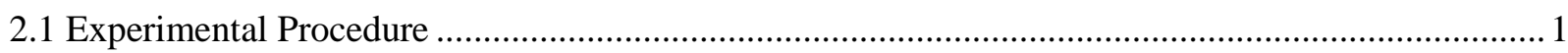

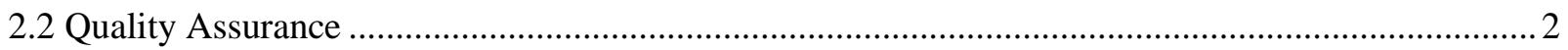

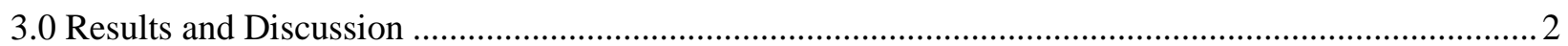

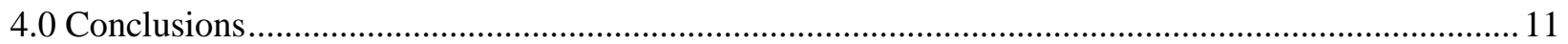

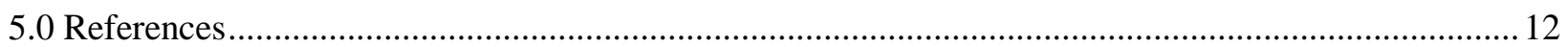




\section{LIST OF TABLES}

Table 2-1 Log of recent trims to the MCU solvent and sample arrivals to SRNL.................................... 1

Table 2-2 Nominal concentrations of the relevant components in NGS Blend ${ }^{2}$...................................... 2

Table 3-1 Sample Results for MCU-15-815-816-817-818-819-820 …................................................... 5

\section{LIST OF FIGURES}

Figure 1. Typical appearance of the six vials MCU-15-815, MCU-15-816, MCU-15-817, MCU-15-818, MCU-15-819, and MCU-15-820

Figure 2 FTIR analysis of the insoluble material found at the bottom of the p-nut vial of MCU-15-815.... 4

Figure 3 Modifier level in the solvent as measured by HPLC (one sigma is 10\%)................................ 6

Figure 4. Suppressor concentration as measured by titration in SHT samples since NGS implementation. The minimum recommended level is $479 \mathrm{mg} / \mathrm{L}$ for TiDG.

Figure 5. MaxCalix concentration as measured by HPLC and FT-HNMR of recent samples since NGS implementation $(44,400 \mathrm{mg} / \mathrm{L}$ is the nominal concentration)........................................................ 8

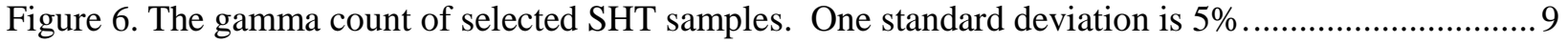

Figure 7. Total mercury in recent SHT samples. One standard deviation is $20 \%$. CVAA = Cold Vapor Atomic Absorption Spectrometry. XRF =X-ray Fluorescence. 


\section{LIST OF ABBREVIATIONS}

BOBCalixC6 Calix[4]arene-bis(tert-octylbenzo-crown-6)

CVAA Cold Vapor Atomic Absorption Spectrometry

FT-HNMR Fourier Transform Hydrogen Nuclear Magnetic Resonance

FTIR Fourier transform infra-red spectroscopy

HPLC High Performance Liquid Chromatography

ISDP Integrated Salt Disposition Project

MCU Modular Caustic-Side Solvent Extraction Unit

MaxCalix 1,3-alt-25,27-Bis(3,7-dimethyloctyloxy)calix[4]arene-benzocrown-6

NGS Next Generation Solvent

RSD Relative Standard Deviation or the absolute value of the Coefficient of Variation

SHT Solvent Hold Tank

SRNL Savannah River National Laboratory

SVOA Semi-Volatile Organic Analysis

TiDG $\quad N, N$ ', $N$ "-tris(3,7-dimethyloctyl)guanidine

TOA Trioctylamine

XRF X-Ray Fluorescence 


\subsection{Introduction}

In late FY13, the Modular Caustic-Side Solvent Extraction Unit (MCU) switched to the Next Generation Solvent (NGS) flow sheet. Facility personnel implemented the switch by adding a non-radioactive, NGS "cocktail" containing the new extractant (MaxCalix) and a new suppressor (TiDG) to the SHT heel. The resulting "blend" solvent ("NGS Blend solvent") is essentially NGS with residual amounts of BOBCalixC6 and trioctylamine (TOA). SHT samples are sent to SRNL to examine solvent composition changes over time. ${ }^{1}$ On November 29,2015 , Operations personnel pulled and delivered six samples from the SHT (MCU-15-815, MCU-15-816, MCU-15-817, MCU-15-818, MCU-15-819, and MCU-15-820) for analysis. These samples are intended to verify that the solvent is within the specified composition range. A baseline "scratch" solvent (a scratch solvent is a preparation of all 6 solvent components at the same time to generate a solution of the appropriate composition that approximates the blend of cocktail ${ }^{2}$ and heel solvent) was prepared in the lab (May 14, 2014) and used for comparison and evaluation. The results from the analyses are presented in this document.

\subsection{Experimental Procedure}

\subsection{Experimental Procedure}

A summary of relevant and recent trims to the MCU solvent as well as the arrival date of the samples currently being studied are shown in Table 2-1. In November 2015, a trim addition was made to MCU that was $10.02 \mathrm{E} 3$ grams of modifier and 765 grams of TiDG in 18.6 gallons of Isopar ${ }^{\mathrm{TM}} \mathrm{L}$.

Table 2-1 Log of recent trims to the MCU solvent and sample arrivals to SRNL

\begin{tabular}{||l|l||}
\hline Event & Date \\
\hline February solvent trim added to MCU & February 22, 2015 \\
\hline SHT sample MCU-15-389-390 & February 25, 2015 \\
\hline SHT sample MCU-15-439-440-441 & February 28, 2015 \\
\hline 20 gallons of Isopar ${ }^{\text {TM }}$ added to MCU & March 6, 2015 \\
\hline SHT sample MCU-15-556-557-558 & March 16, 2015 \\
\hline SHT sample MCU-15-661-662-663 & April 2, 2015 \\
\hline 10 gallons of Isopar ${ }^{\text {TM }}$ added to MCU & May 6, 2015 \\
\hline SHT sample MCU-15-710-711-712 & June 15, 2015 \\
\hline SHT sample MCU-15-750-751-752 & June 22, 2015 \\
\hline SHT sample MCU-15-802-803-804-805-806-807 & August 31, 2015 \\
\hline November solvent trim added to MCU & November 28, 2015 \\
\hline SHT sample MCU-15-815-816-817-818-819-820 & November 29, 2015 \\
\hline
\end{tabular}

Samples shown in Table 2-1 were received in p-nut vials containing 10 mL each (see Fig 1). Once taken into a radioactive hood, the samples were visually inspected and analyzed for pH. MCU-15-815, MCU15-816, MCU-15-817, MCU-15-818, MCU-15-819, and MCU-15-820 were composited before use. Aliquots of the composited sample were removed to perform the following analysis: Density, semivolatile organic analysis (SVOA), high performance liquid chromatography (HPLC), titration, gamma counting, cold vapor atomic adsorption spectrometry (CVAA), X-ray fluorescence (XRF), and FourierTransformed Hydrogen Nuclear Magnetic Resonance (FT-HNMR). Results from analytical measurements were compared with the theoretical values shown in Table 2-2. 
Table 2-2 Nominal concentrations of the relevant components in NGS Blend ${ }^{2}$

\begin{tabular}{|c|c|c|}
\hline Component & mg/L & Molar \\
\hline MaxCalix & $\sim 44,400$ & $\sim 0.0465$ \\
\hline BOBCalixC6 $^{*}$ & $<4,030$ & $<0.0035$ \\
\hline TOA $^{*}$ & $<530$ & $<0.0015$ \\
\hline Modifier & $\sim 169,000$ & $\sim 0.50$ \\
\hline TiDG & $\sim 1440$ & $\sim 0.003$ \\
\hline Isopar ${ }^{\mathrm{TM} L}$ & $\sim 623,000$ & $\sim 74 \mathrm{wt} \%$ \\
\hline
\end{tabular}

*Values represent starting values when NGS blend was implemented. These components are no longer added to or refurbished in MCU.

\subsection{Quality Assurance}

Requirements for performing reviews of technical reports and the extent of review are established in manual E7 2.60. SRNL documents the extent and type of review using the SRNL Technical Report Design Checklist contained in WSRC-IM-2002-00011, Rev. 2.

\subsection{Results and Discussion}

Each sample (MCU-15-815, MCU-15-816, MCU-15-817, MCU-15-818, MCU-15-819, and MCU-15820) was visually examined. Most were found to contain a single phase liquid with no apparent solids contamination or cloudiness. However, insoluble material was found at the bottom of the p-nut vial from sample MCU-15-815. The material had a $\mathrm{pH}$ value of 11 . That material was a heterogeneous mixture of materials and compounds (as determined by the FTIR method shown in Fig. 2) that included oxidized modifier (containing $\mathrm{C}=\mathrm{O}$ and aliphatic $\mathrm{C}=\mathrm{C}$ groups), cellulose, bacteria, sodium sulfite, magnesium silicate and talc. Since no insoluble material was found in the other MCU samples, it was concluded that the material found in MCU-15-815 was residual material left in the piping that flushed into the p-nut vial of MCU-15-815 (MCU-15-815 was the first p-nut that was filled) at the beginning of sampling the SHT. It was also concluded that this de-minimis insoluble material had no chemical or physical impact on the solvent performance. All samples had a $\mathrm{pH}$ value of 5.5. No unusual reactions, solids, foaming, or immiscible layers were observed after combining the samples into one (MCU-15-815-816-817-818-819820). Table 3-1 contains the results for the MCU-15-815-816-817-818-819-820 composite sample.

Isopar $^{\mathrm{TM}} \mathrm{L}$ and Modifier Levels

A density measurement of the sample gave a result of $0.8377 \mathrm{~g} / \mathrm{mL}(0.03 \% \mathrm{RSD}$ ) (or $0.8326 \mathrm{~g} / \mathrm{mL}$ at $25{ }^{\circ} \mathrm{C}$ when corrected for temperature using the CSSX temperature correction formula) for MCU-15-815816-817-818-819-820 at $19{ }^{\circ} \mathrm{C}$. The calculated density $(0.8326 \mathrm{~g} / \mathrm{mL})$ for MCU-15-815-816-817-818$819-820$ is less than $1 \%$ below the calculated density for the standard sample $\left(0.835 \mathrm{~g} / \mathrm{mL}\right.$ at $25{ }^{\circ} \mathrm{C}$ for the scratch blend made in the laboratory $)^{\mathrm{i}}$. Using the density as a starting point, we know that the concentration level of the Isopar ${ }^{\mathrm{TM}} \mathrm{L}$ component in the sample should be equal to the nominal value (within analytical uncertainties). 


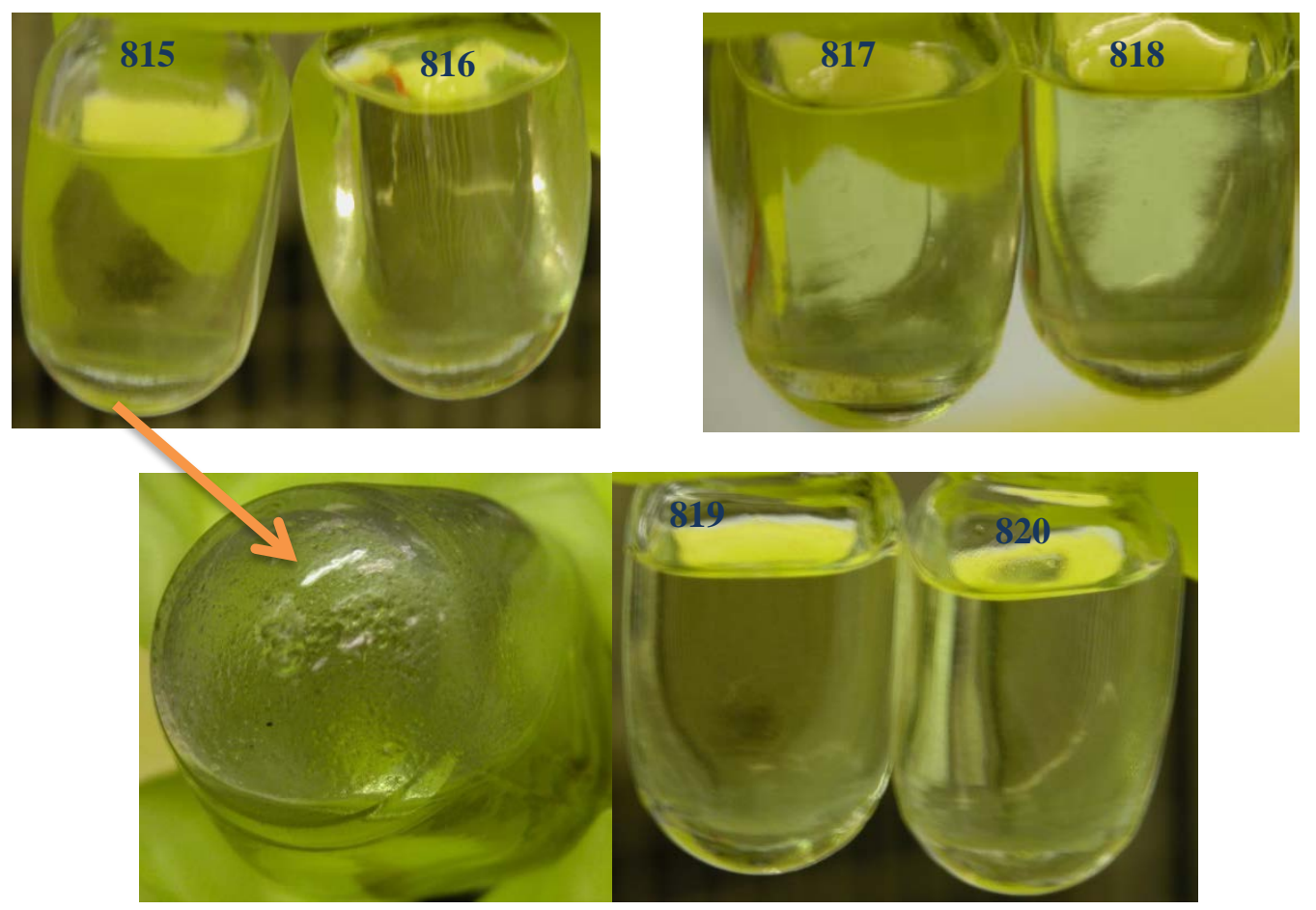

Figure 1. Typical appearance of the six vials MCU-15-815, MCU-15-816, MCU-15-817, MCU-15818, MCU-15-819, and MCU-15-820

An examination of Table 3-1 shows that the Isopar $^{\mathrm{TM}} \mathrm{L}$ concentration is at its nominal value while the modifier concentration is correspondingly slightly lower (3\% lower) than its nominal value. Of all the methods listed, density has the lowest uncertainty. Thus, the final reported values are closer to the density measurement. The last Isopar ${ }^{\mathrm{TM}} \mathrm{L}$ trim addition to MCU was in November 2015.

All measurements indicate the Isopar ${ }^{\mathrm{TM}} \mathrm{L}$ level is at nominal value while the modifier concentration level is below its nominal value (see Fig. 3 for recent modifier concentrations from HPLC measurements). The modifier level appears to trend up and down possibly reflecting randomness in the process of mixing, sampling and analyzing it. The relatively lower modifier concentration explains why the measured density is slightly below the standard sample density. The accuracies of the different measurements were within expectation as reflected in the total mass sum of the "average" results listed in Table 3-1. They added up to $0.836 \pm 0.019 \mathrm{~g} / \mathrm{mL}$. Their sum is consistent with the measured and temperature corrected (to $25{ }^{\circ} \mathrm{C}$ ) value of $0.833 \mathrm{~g} / \mathrm{mL}$, and also with the measured and corrected to $25{ }^{\circ} \mathrm{C}$ mass concentration (density) of the standard $(0.835 \mathrm{~g} / \mathrm{mL})$. 

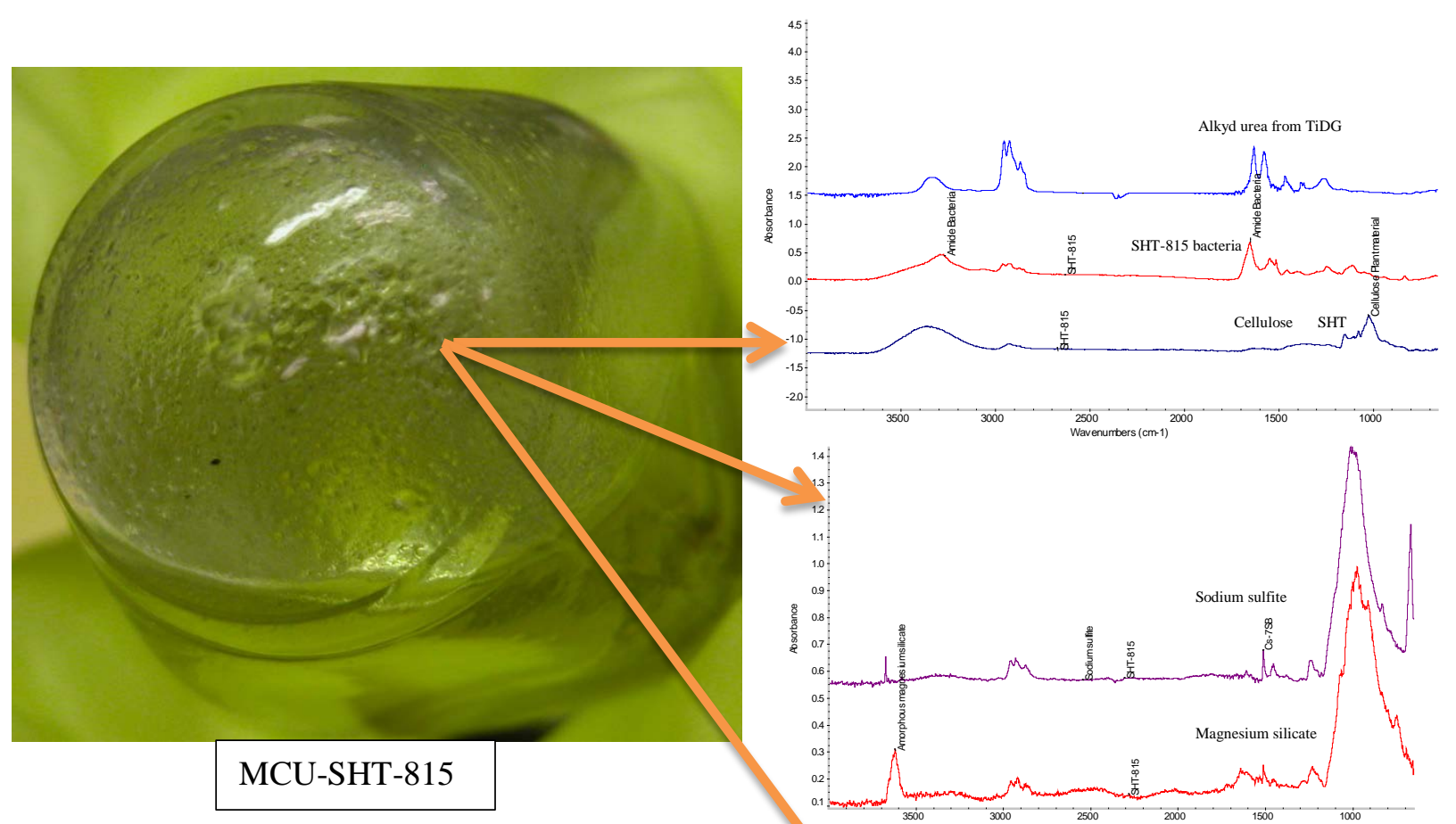

Organic portion

$85 \%$ of the bottom layer is oxidized Cs-7SB containing carbonyl, bacteria (10\%), and cellulose.

Inorganic portion:

Magnesium silicate (amorphous and crystalline) Magnesium aluminosilicate

Sodium sulfite

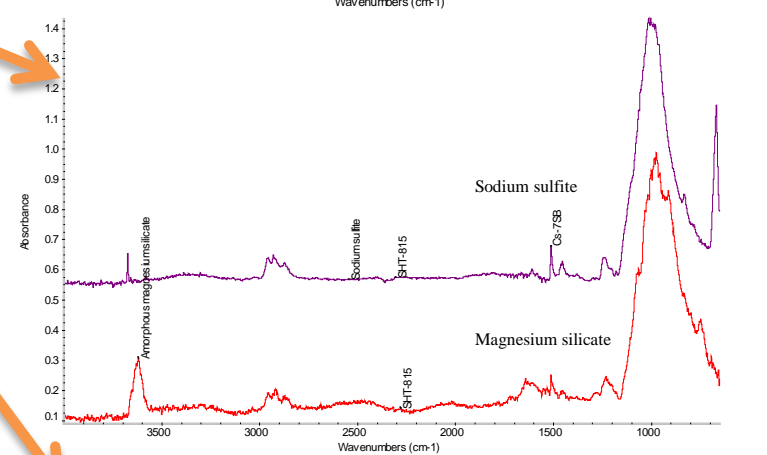

Figure 2 FTIR analysis of the insoluble material found at the bottom of the p-nut vial of MCU-15815 
Table 3-1 Sample Results for MCU-15-815-816-817-818-819-820

\begin{tabular}{|c|c|c|c|c|c|}
\hline Analysis & Method & LIMS \# & $\begin{array}{l}\text { Result } \\
(\mathrm{mg} / \mathrm{L})^{\#}\end{array}$ & $\begin{array}{l}\text { Nominal* Result } \\
(\mathbf{m g} / \mathrm{L})\end{array}$ & $\begin{array}{c}\% \text { of (Result } \div \text { Nominal } \\
\text { Result) }\end{array}$ \\
\hline Isopar $^{(\mathbb{R}} \mathrm{L}$ & FTIR & NA & $6.22 \mathrm{E}+05$ & \multirow{3}{*}{$6.23 E+05$} & 100 \\
\hline Isopar $^{(B)} \mathrm{L}$ & FT-HNMR & NA & $6.42 \mathrm{E}+05$ & & 103 \\
\hline Isopar ${ }^{(B)} \mathrm{L}$ & Density $^{*}$ & NA & $6.23 \mathrm{E}+05$ & & 100 \\
\hline Average $^{\$}$ & All & NA & $6.24 \mathrm{E}+05$ & $6.23 \mathrm{E}+05$ & 100 \\
\hline Modifier & HPLC & 300319891 & $1.61 \mathrm{E}+05$ & \multirow{4}{*}{$1.69 \mathrm{E}+05$} & 95 \\
\hline Modifier & FT-HNMR & NA & $1.63 \mathrm{E}+05$ & & 96 \\
\hline Modifier & FTIR & NA & $1.62 \mathrm{E}+05$ & & 96 \\
\hline Modifier & Density $^{*}$ & NA & $1.64 \mathrm{E}+05$ & & 97 \\
\hline Average $^{\text {S }}$ & All & NA & $1.64 \mathrm{E}+05$ & $1.69 \mathrm{E}+05$ & 97 \\
\hline $\mathrm{TiDG}^{\star}$ & Titration & NA & $1.55 \mathrm{E}+03$ & $1.44 \mathrm{E}+03$ & 107 \\
\hline Average $^{\$}$ & All & NA & $1.55 \mathrm{E}+03$ & $1.44 \mathrm{E}+03$ & 107 \\
\hline trioctylamine & Titration & NA & $2.92 \mathrm{E}+02$ & $5.30 \mathrm{E}+02$ & 55 \\
\hline Average $^{\$}$ & All & NA & $2.92 \mathrm{E}+02$ & $5.30 \mathrm{E}+02$ & 55 \\
\hline MaxCalix & FT-HNMR & NA & $4.35 \mathrm{E}+04$ & \multirow{2}{*}{$4.44 \mathrm{E}+04$} & 98 \\
\hline MaxCalix & HPLC & 300319891 & $4.43 \mathrm{E}+04$ & & 100 \\
\hline Average $^{\$}$ & All & NA & $4.40 \mathrm{E}+04$ & $4.44 \mathrm{E}+04$ & 99 \\
\hline BOBCalixC6 & HPLC & 300319891 & $2.95 \mathrm{E}+03$ & $4.03 \mathrm{E}+03$ & 73 \\
\hline Average $^{\$}$ & All & NA & $2.95 \mathrm{E}+03$ & $4.03 \mathrm{E}+03$ & 73 \\
\hline $\begin{array}{l}\text { Density } \\
(\mathrm{g} / \mathrm{mL})\end{array}$ & $\begin{array}{c}\text { Direct } \\
\text { Measurement } \\
\end{array}$ & NA & 0.8326 & 0.835 & 100 \\
\hline
\end{tabular}

${ }^{\#}$ Analytical uncertainty is $10 \%$ for HPLC. Titration method uncertainty is $10 \%$ for TiDG and $20 \%$ for TOA. Density results from the average of replicate volumetric trials typically have a percentage standard deviation of $<3 \%$ between each value and the average. NMR analytical uncertainty is $10 \%$ for the modifier and $13 \%$ for MaxCalix, $14 \%$ for Isopar ${ }^{\mathrm{TM}} \mathrm{L}$, and $20 \%$ for TiDG. N/A = Not Applicable. Density estimations assume the combined weight percent of TiDG,MaxCalix,BOBCalixC6, and TOA to be approximately 6\%.

${ }^{*}$ Nominal value is the expected value for freshly prepared blended solvent with a target density of $0.8352 \mathrm{~g} / \mathrm{mL}$ at $25^{\circ} \mathrm{C}$.

$\$ x=\frac{\sum_{1}^{i}\left(x_{i} / \delta_{i}^{2}\right)}{\sum_{1}^{i}\left(1 / \delta_{i}^{2}\right)} ; \quad \begin{aligned} & x_{i} \text { stands for the concentration obtained at a given method and } \delta_{i} \text { is the } \\ & \text { corresponding uncertainty. }\end{aligned}$

^ No TiDG value was estimated by FTHNMR due to an aged (questionable) standard. 


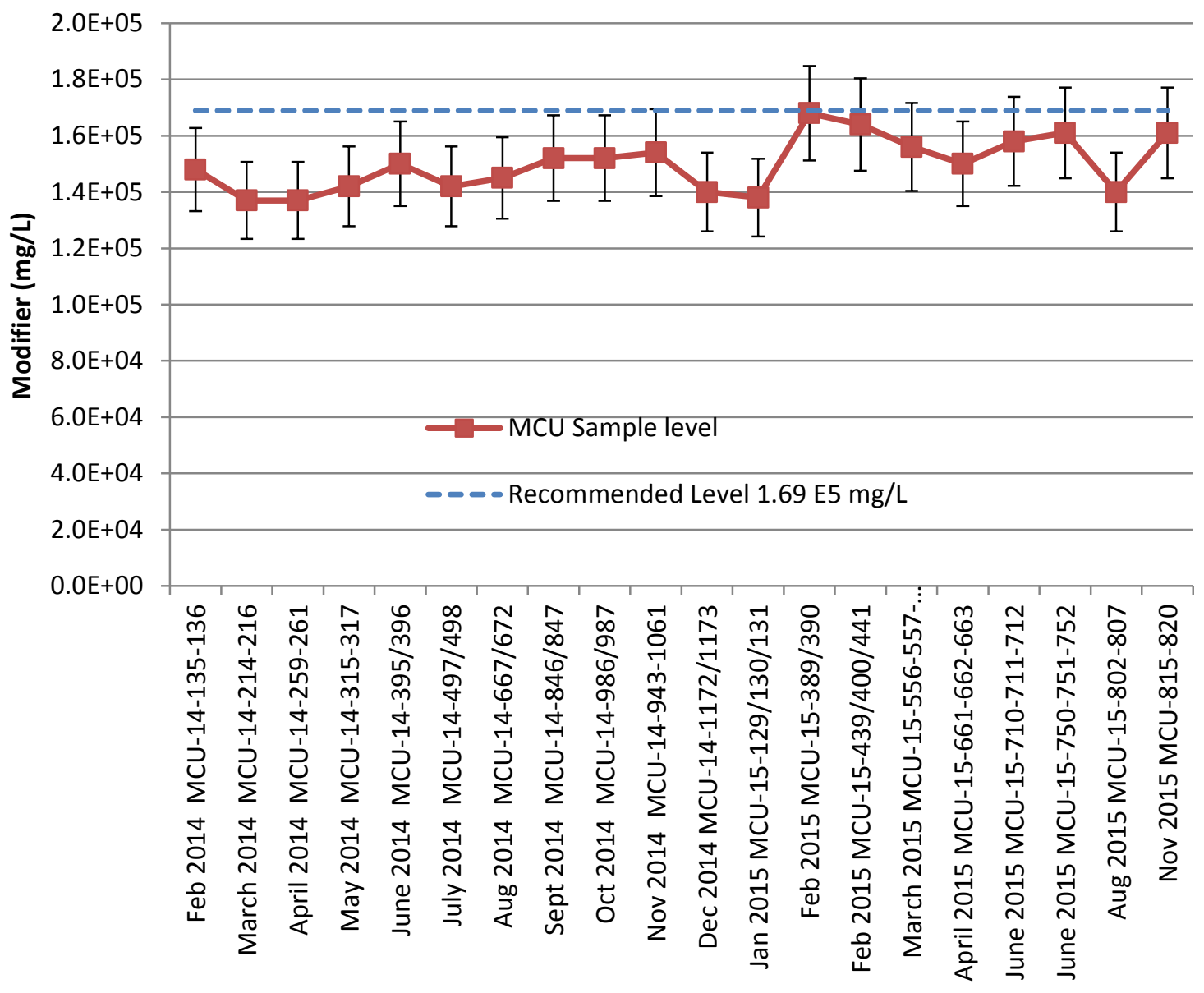

Figure 3 Modifier level in the solvent as measured by HPLC (one sigma is $10 \%$ ).

\section{Suppressors Levels}

The average TiDG concentration level $(1.55 \pm 0.2 \mathrm{E} 3 \mathrm{mg} / \mathrm{L})$ is at $107 \%$ of its nominal value of 1440 $\mathrm{mg} / \mathrm{L}$ confirming the trim addition to the solvent done in November 2015 (a noticeable spike in the TiDG concentration level was observed in Fig. 4). The suppressor concentration is above the minimum recommended operating level $(479 \mathrm{mg} / \mathrm{L})$ and thus, the solvent did not require a TiDG addition at the time sample MCU-15-815-816-817-818-819-820 was collected. Inferring from past TiDG concentration level trends and in the absence of new additions or new removal mechanisms, the TiDG concentration is expected to drop as shown in Fig. 4. This drop is due to the combined effect of auto-decomposition and phase transfer to the aqueous phases (salt solution and boric acid). The TOA concentration appears to have remained steady $292 \pm 58 \mathrm{mg} / \mathrm{L}$ (in the previous sample the TOA level was at $311 \mathrm{mg} / \mathrm{L}$ ). These numbers are within analytical error. In addition, looking at the slope of the TOA concentration data, it appears to trend downwards with time after the trim addition (TiDG). The TOA's concentration level trend appears to anti-correlate with the TiDG's concentration level trend (or the disappearance of IsoparTM $^{\mathrm{TM}}$ due to evaporation). This anti-correlation is believed to be due to the combined effects of titration of TiDG's decomposition products, dilution effects from the trimming, and to the evaporation of Isopar $^{\mathrm{TM}} \mathrm{L}$. Since MCU no longer adds TOA, a drop in TOA concentration is expected with time. The drop in the TOA concentration level, right after the trim addition, is possibly due to the dilution effect of the trim (see Fig. 4). Based on previous historical trends the TOA concentration is expected to increase. The increase is perhaps due to TiDG degradation into primary amines, which have previously been 
identified as degradation products of the suppressor when heated. ${ }^{3}$ The primary amine degradation products would likely have a similar pKa to the TOA (tertiary amine) making the equivalent points coincide. $^{4}$

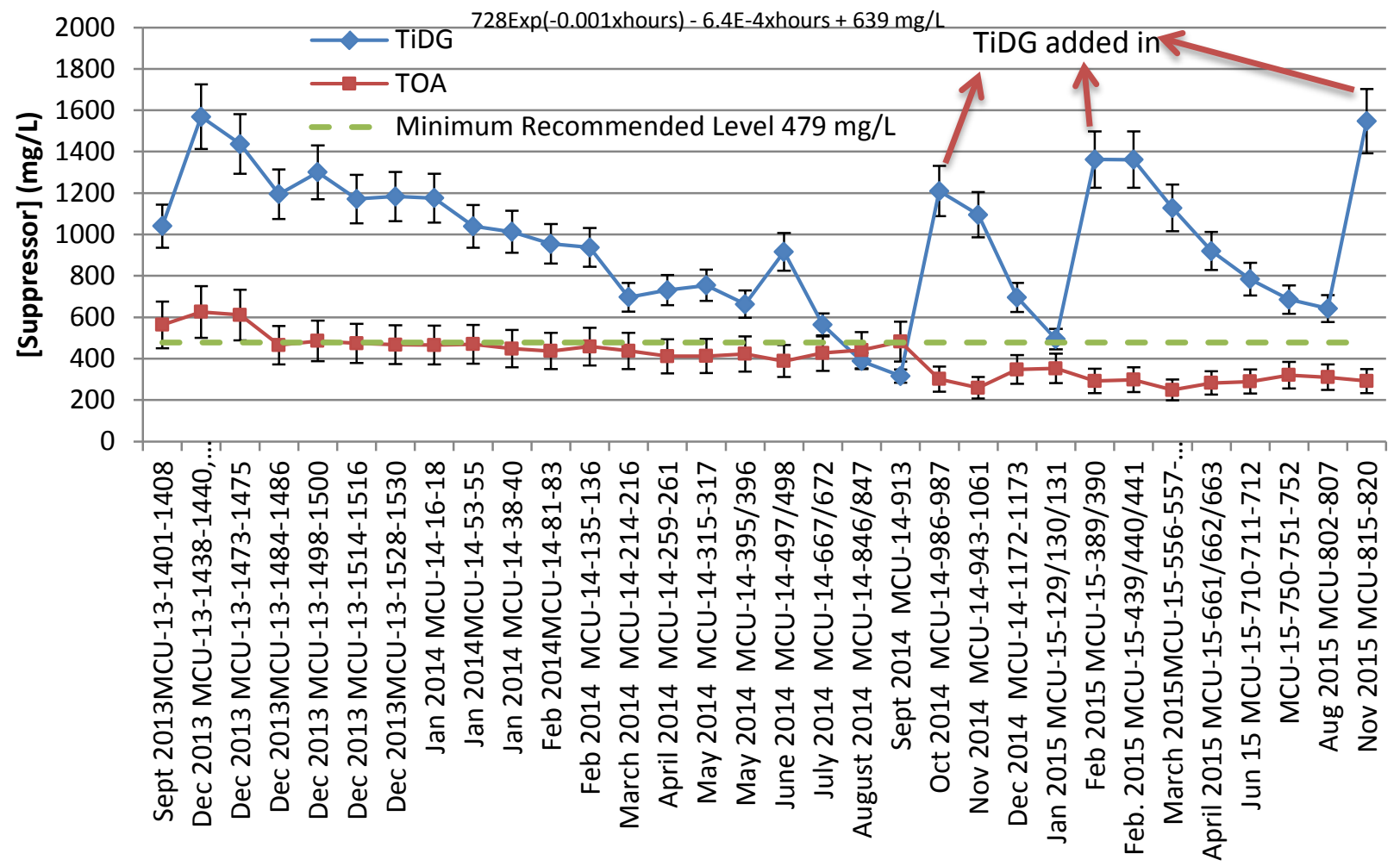

Figure 4. Suppressor concentration as measured by titration in SHT samples since NGS implementation. The minimum recommended level is $479 \mathrm{mg} / \mathrm{L}$ for TiDG.

\section{Extractant Levels}

The average MaxCalix level is $4.40 \mathrm{E} 4 \mathrm{mg} / \mathrm{L}( \pm 13 \%)$ which is $1 \%$ below the nominal concentration and it is within the $95 \%$ confidence level of the analytical measurement as shown in Figure 5. The residual concentration of BOBCalixC6 level is currently at 73\% of the level measured when the NGS was implemented in late FY13. 
SRNL-STI-2016-00016

Revision 0

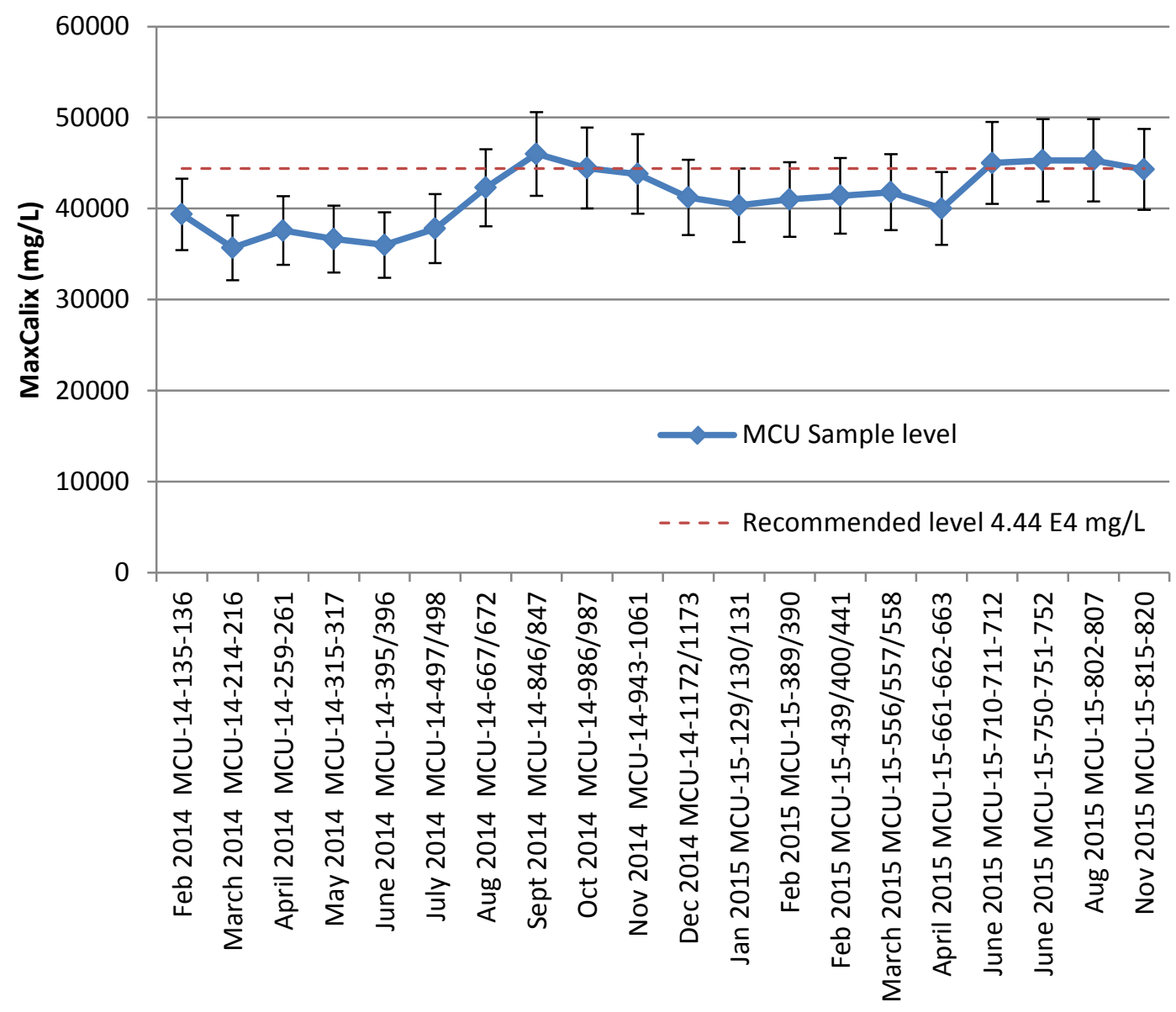

Figure 5. MaxCalix concentration as measured by HPLC and FT-HNMR of recent samples since NGS implementation $(44,400 \mathrm{mg} / \mathrm{L}$ is the nominal concentration).

\section{Gamma Level}

The gamma measurement of MCU-15-815-816-817-818-819-820 is $3.42 \mathrm{E}+05 \mathrm{dpm} / \mathrm{mL}( \pm 5 \%)$. This level of activity appears to indicate an upward trend in the data (see Fig. 6) and in recent past, an apparent correlation was observed between poor extraction and/or stripping performance of the solvent and high gamma activity levels in the solvent. 


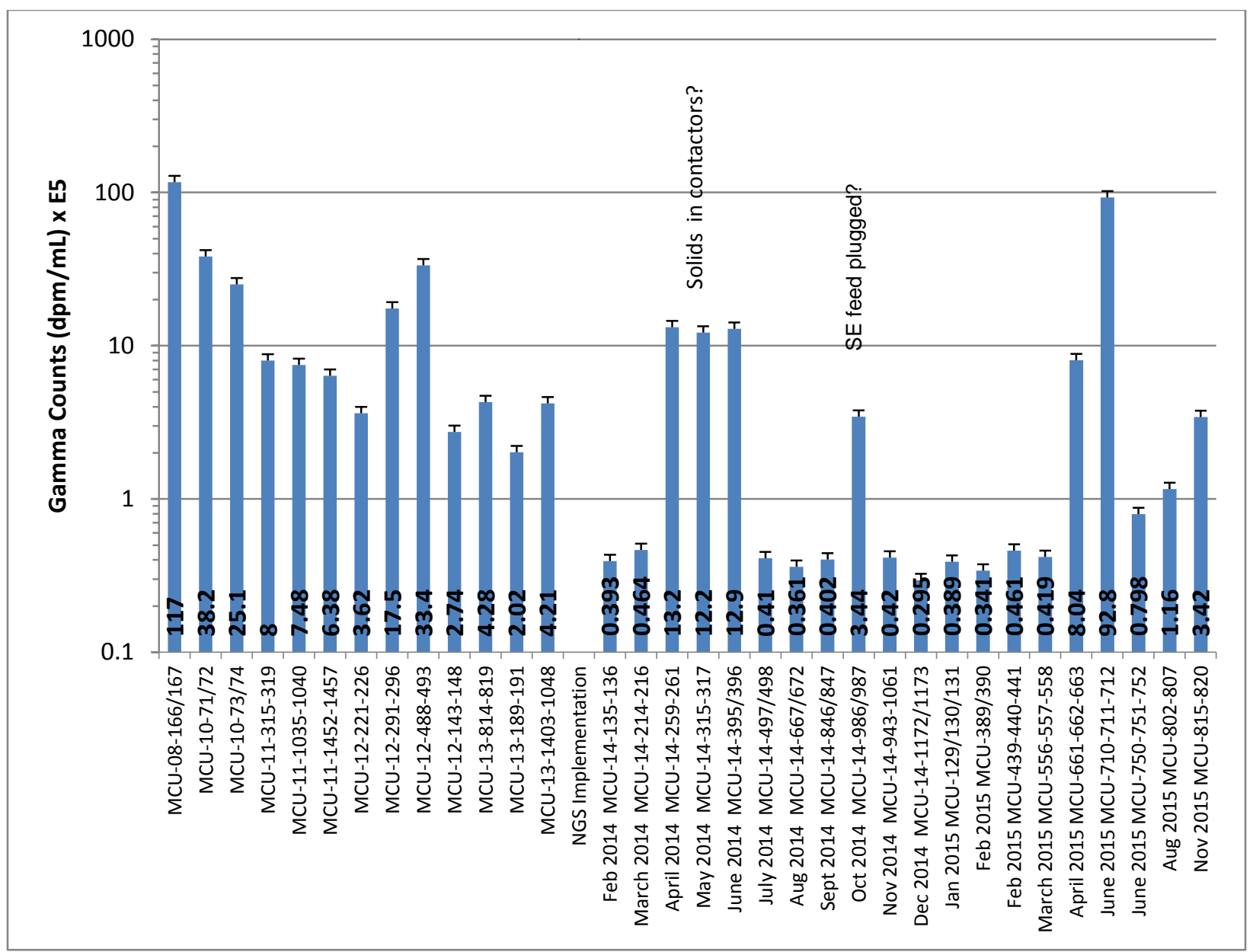

Figure 6. The gamma count of selected SHT samples. One standard deviation is $5 \%$.

\section{Impurities}

No impurities were seen at the $1000 \mathrm{ppm}$ level or higher as indicated by the SVOA method ( $\pm 20 \%$ uncertainty). No impurities were observed in the FTIR or in the HNMR spectrum of this sample after subtracting the scratch solvent spectrum.

A few $\mathrm{mL}$ of the blended solvent were digested and analyzed for mercury (by the cold vapor method and the XRF method). The total mercury level in the solvent measured $12.5 \mu \mathrm{g} / \mathrm{g}_{\text {solvent }}$ (20\% st.dev.) or 10.4 $\mu \mathrm{g} / \mathrm{mL}_{\text {solvent. }}$ This is significantly higher than the solubility of metallic $\mathrm{Hg}$ in dodecane $(\sim 3 \mathrm{ppm})^{5}$ implying that other solubility-enhancing mechanisms are at play (for example extraction by an extractant or sorption on trapped solids) or a more soluble form of mercury is present (organo-mercury like ethyl or dimethyl mercury). Organo-mercury compounds were recently detected in Tank 22H. ${ }^{6}$ For 200 gallons of solvent $(757.1 \mathrm{~L})$ and assuming a density of $0.833 \mathrm{~g} / \mathrm{mL}$, the solvent could contain a total of $7.9 \pm 2 \mathrm{~g}$ of mercury. See figure 7 for a comparison of recent SHT mercury concentrations. No mercury was observed in this sample by the XRF method. 


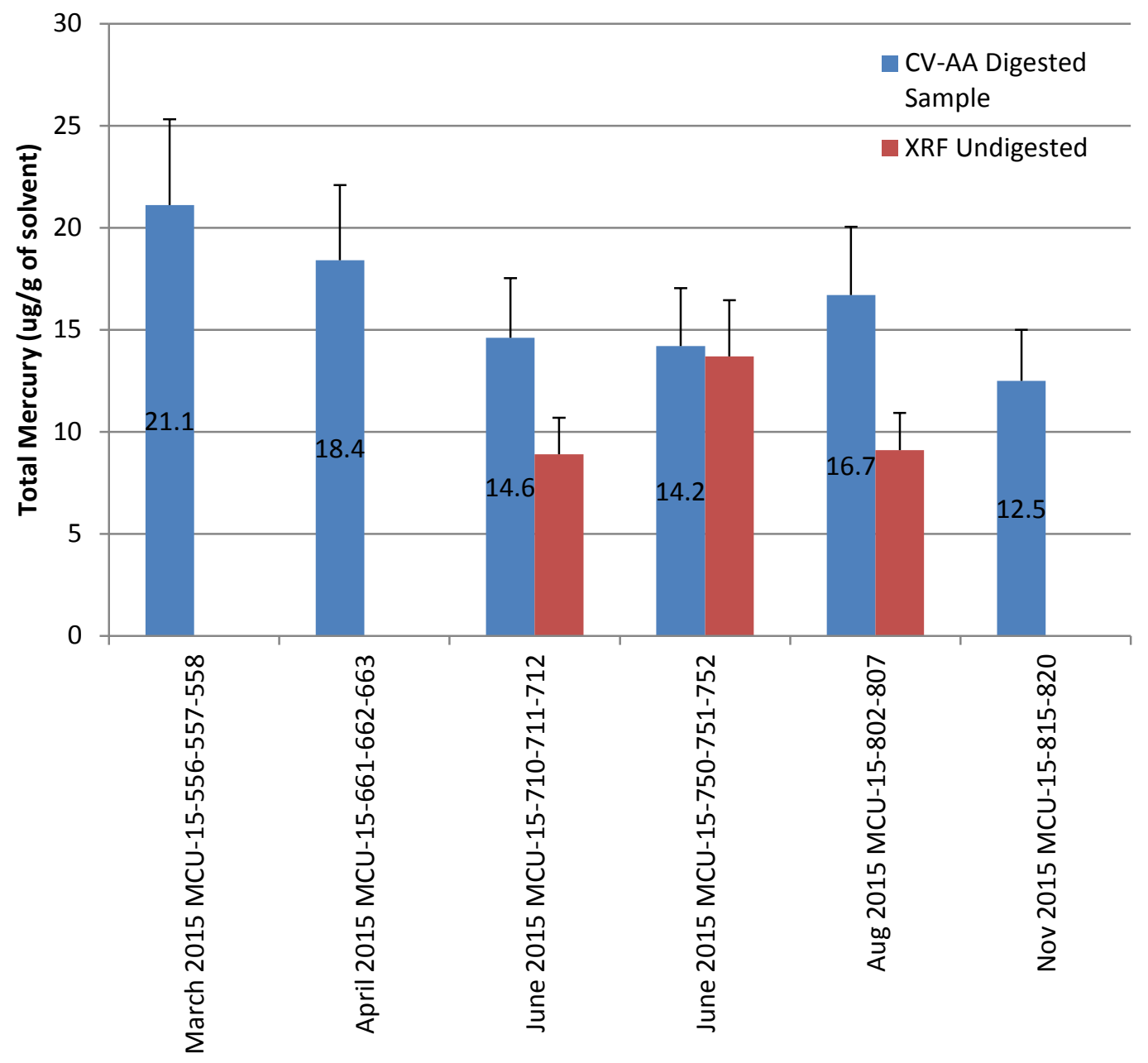

Figure 7. Total mercury in recent SHT samples. One standard deviation is $20 \%$. CVAA $=$ Cold Vapor Atomic Absorption Spectrometry. XRF =X-ray Fluorescence.

\section{Recommendation}

The current analysis indicates the solvent has a slightly lower modifier level but nominal levels of TiDG, Isopar ${ }^{\mathrm{TM}} \mathrm{L}$ and MaxCalix relative to the standard. The TiDG, MaxCalix and Isopar ${ }^{\mathrm{TM}} \mathrm{L}$ levels are expected to trend downward with time. In order to remain two-sigma above the minimum recommended level, it is recommended to continue the periodic surveillance of and trimming additions to the solvent. 


\subsection{Conclusions}

SRNL received one set of SHT samples (MCU-15-815-816-817-818-819-820), pulled on 11/29/2015 for analysis. The samples were combined and analyzed for composition. Analysis of the composite sample MCU-15-815-816-817-818-819-820 indicated the TiDG, Isopar ${ }^{\mathrm{TM}} \mathrm{L}$, and MaxCalix are at nominal levels. The modifier concentration is $3 \%$ below its nominal concentration. This analysis confirms the addition of TiDG, MaxCalix, and modifier to the solvent in November 2015. Based on the current monthly sample, the levels of TiDG, Isopar ${ }^{\mathrm{TM}} \mathrm{L}$, MaxCalix, and modifier are sufficient for continuing operation but are expected to decrease with time. Periodic characterization and trimming additions to the solvent are recommended.

No impurities above the $1000 \mathrm{ppm}$ level were found in this solvent by the Semi-Volatile Organic Analysis (SVOA). No impurities were observed in the Hydrogen Nuclear Magnetic Resonance (HNMR). However, up to $12.5 \pm 3$ micrograms of mercury per gram of solvent (or $10.4 \mu \mathrm{g} / \mathrm{mL}$ ) was detected in this sample. The solids residues found at the bottom of the p-nut vial from sample MCU-15-815 were determined to be left-over pipe residues that were flushed into the sample and they were found to have no impact on the solvent purity or on the chemical and physical properties of the solvent.

The laboratory will continue to monitor the quality of the solvent in particular for any new impurities or degradation of the solvent components. 


\subsection{References}

${ }^{1}$ W. M. Matthews, HLW-CRF-10006, Rev. 0, May 18, 2010.

${ }^{2}$ T. B. Peters and M. R. Williams, "Results of Analysis of NGS Concentrate Drum Samples” SRNL-STI2013-00521, September 2013.

${ }^{3}$ B. A Moyer, L. H. Delmau, B. D. Roach, and N. J. Williams, “Thermal Degradation of Next Generation Solvent using Triisodecylguanidine Suppressor: Impacts on Solvent Performance and Organic Content of Aqueous Effluents” ORNL-LTR-NGCSSX-020, Rev. 1, July 2013.

${ }^{4}$ K. M. L. Taylor-Pashow, F. F. Fondeur, T. L. White, D. P. Diprete, and C. E. Milliken, "Development of Analytical Methods for Determining Suppressor Concentration in the MCU Next Generation Solvent (NGS)” SRNL-STI-2013-00435, Rev. 0, July 2013.

${ }^{5}$ H. L. Clever and M. Iwamoto, “Solubility of Mercury in Normal Alkanes”, Ind. Eng. Chem. Res. (1987), 26, 336-337.

${ }^{6}$ C. J. Bannochie, "Result of Preliminary Hg Speciation Testing on Tank 22 and Waste Concentrate Hold Tank (WCHT) Material”, SRNL-L3100-2015-00079, Rev. 1, May 4, 2015. 


\section{Distribution:}

A. P. Fellinger, 773-43A

T. B. Brown, 773-A

M. E. Cercy, 773-42A

D. A. Crowley, 773-43A

D. E. Dooley, 773-A

S. D. Fink, 773-A

C. C. Herman, 773-A

D. T. Hobbs, 773-A

E. N. Hoffman, 999-W

J. E. Hyatt, 773-A

K. M. Kostelnik, 773-42A

B. B. Looney, 773-42A

D. A. McGuire, 773-42A

T. O. Oliver, 773-42A

F. M. Pennebaker, 773-42A

G. N. Smoland, 773-42A

M. E. Stone, 999-W

A. L. Washington, 773-42A

W. R. Wilmarth, 773-A

Records Administration (EDWS)

E. A. Brass, 241-121H

C. K. Chiu, 704-27S

J. S. Contardi, 704-56H

A. G. Garrison, 241-121H

C. M. Santos, 241-152H

P. E. Fogelman, 241-121H

C. J. Scherman, 241-152H

B. A. Gifford, 704-56H

R. T. McNew, 766-H

P. R. Jackson, DOE-SR, 703-46A

J. A. Crenshaw, 703-46A

T. B. Peters, 773-42A

C. A. Nash, 773-42A

F. F. Fondeur, 773-A

K. M. L. Taylor-Pashow, 773-A

D. H. Jones, 999-W 